\title{
F Faculty
}

A Aid to

A CPD Self-Assessment Test

C CPD

T Topics

ANSWER SHEET

Review No. 2002/03

To be reviewed not later than $30^{\text {th }}$ September 2007

\section{Assisting and advising complainants of sexual assault in the family planning setting}

Answer

1. The increase in reported rapes in the past decade is due to an increase in the number of reported stranger rapes.

False

2. Teenagers are most likely to be sexually assaulted by a member of their family.

False

3. Following fellatio three types of sample are obtained from the mouth.

True

4. Spermatozoa only persist for up to 3 days in the vagina/cervical canal.

False

5. Defaecation removes all spermatozoa from the anal canal/rectum.

False

6. Ideally KY Jelly should not be used when a speculum/proctoscope is used to obtain forensic samples.

True

7. The swabs for forensic analysis are the same as those used for bacteriological analysis.

False

8. For forensic purposes the products of conception should be placed into a plain container which has not been used for anything else.

9. Alcohol is the most common substance detected on toxicological analysis of urine samples from complainants of sexual assault.

10. There is no point obtaining samples for toxicology if a complainant presents more than 48 hours after a possible substance facilitated sexual assault.

False

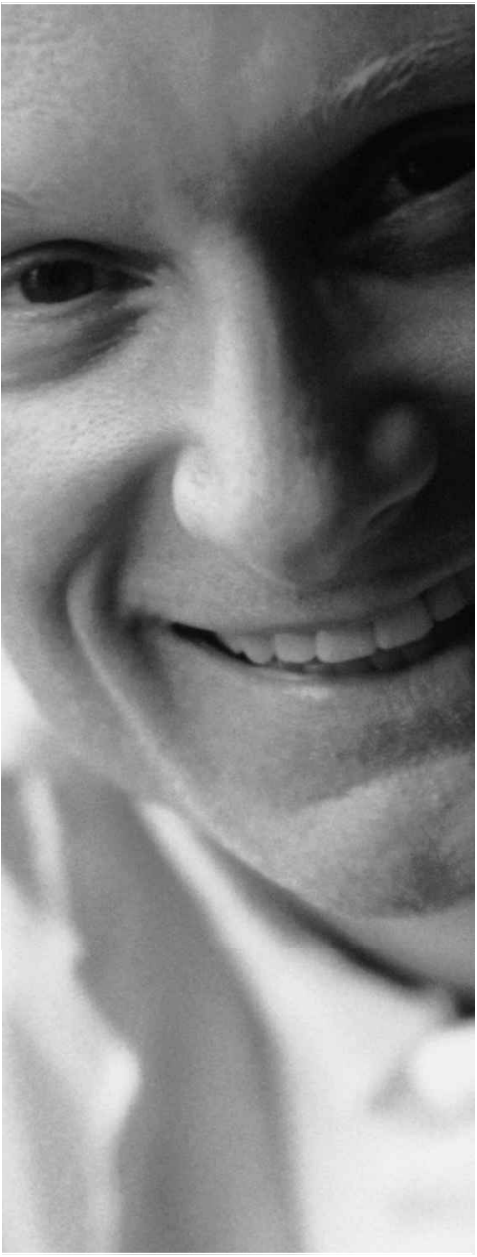

VASECTOMY SERVICES

\section{QUICK, RELIABLE,} STRAIGHTFORWARD. THE PROFESSIONAL CHOICE.

MARIE STOPES INTERNATIONAL IS A LEADING CHARITY IN THE FIELD OF FAMILY PLANNING. WE WORK CLOSELY WITH THE NHS TO PROVIDE VASECTOMY SERVICES. WE ARE ALSO HAPPY TO ACCEPT PRIVATE REFERRALS FOR PATIENTS WISHING TO AVOID WAITING LISTS.

HAVING PERFORMED OVER 100,000 VASECTOMIES, WE ARE THE COUNTRY'S MOST EXPERIENCED PROVIDER. OUR 25 VASECTOMY CENTRES NATIONWIDE OFFER A QUICK, RELIABLE AND STRAIGHTFORWARD SERVICE. OUR VASECTOMY TECHNIQUE TAKES JUST A FEW MINUTES AND REQUIRES NO STITCHES.

YOU CAN TRUST US TO TAKE CARE OF THE PATIENTS YOU REFER AND TO PROVIDE A FULL

\section{CALL US ON 08453000212}

OR VISIT WWW.MARIESTOPES.ORG.UK

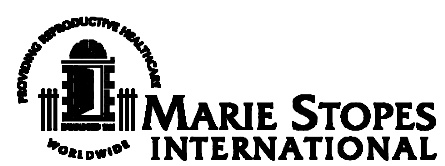

